\title{
NOTE \\ Overexpression of human epidermal growth factor receptor 2 in canine primary lung cancer
}

\author{
Sho YOSHIMOTO'), Daiki KATO')*, Satoshi KAMOTO'), Kie YAMAMOTO²), \\ Masaya TSUBOI ${ }^{2)}$, Masahiro SHINADA ${ }^{1}$, Namiko IKEDA ${ }^{1)}$, Yuiko TANAKA ${ }^{1)}$, \\ Ryohei YOSHITAKE ${ }^{1)}$, Shotaro ETO ${ }^{1)}$, Kohei SAEKI ${ }^{1)}$, James CHAMBERS $^{3)}$, \\ Yuko HASHIMOTO'), Kazuyuki UCHIDA ${ }^{3)}$, Ryohei NISHIMURA ${ }^{1)}$ and \\ Takayuki NAKAGAWA ${ }^{1)}$ \\ 1)Laboratory of Veterinary Surgery, Graduate School of Agricultural and Life Sciences, The University of Tokyo, \\ 1-1-1, Yayoi, Bunkyo-ku, Tokyo 113-8657, Japan \\ ${ }^{2)}$ Veterinary Medical Center, The University of Tokyo, 1-1-1, Yayoi, Bunkyo-ku, Tokyo 113-8657, Japan \\ 3) Laboratory of Veterinary Pathology, Graduate School of Agricultural and Life Sciences, The University of Tokyo, \\ 1-1-1, Yayoi, Bunkyo-ku, Tokyo 113-8657, Japan
}

J. Vet. Med. Sci.

82(6): 804-808, 2020

doi: 10.1292/jvms.20-0026

Received: 15 January 2020

Accepted: 17 March 2020

Advanced Epub: 3 April 2020
ABSTRACT. Human epidermal growth factor receptor 2 (HER2) overexpression has been reported in various human cancers. HER2-targeted therapies showed clinical responses in humans with HER2-positive tumors. The incidence of canine primary lung cancer (CPLC) is increasing, but there are no effective systemic therapies for dogs with late-stage CPLC. HER2-targeted therapy could be an option for CPLC, but HER2 expression in CPLC remains unknown. We evaluated HER2 expression in CPLC. Immunohistochemical analysis revealed that 3 samples (19\%) scored 3+; 8 (50\%), $2+; 5$ ( $31 \%)$; and $1+$ and $0(0 \%), 0$. Of the CPLC tissues, $69 \%$ were HER2 positive (scored $\geq 2+$ ). These data would lead to further evaluation of the role of HER2 in CPLC as a mechanism of malignancy and therapeutic target.

KEY WORDS: Canis familiaris, lung cancer, oncogene protein human epidermal growth factor receptor 2

Human epidermal growth factor receptor 2 (HER2) is a receptor tyrosine kinase and one of the members of the human epidermal growth factor receptor family [2]. HER2 amplification and protein overexpression have been reported in various human cancers, including breast, gastric, and lung cancers [5, 11, 14, 19]. HER2 has been shown as both a diagnostic marker and therapeutic target in these tumors [5]. HER2-targeted therapies, such as lapatinib and trastuzumab, have been developed and showed clinical responses in humans with HER2-positive cancers [1, 8, 22].

In human medicine, lung cancer is the leading cause of cancer-related death worldwide [11]. Approximately $85 \%$ of human lung cancers are non-small cell lung cancers (NSCLCs), which consisted of three distinct histologic subtypes: squamous cell carcinoma, adenocarcinoma, and large-cell carcinoma [15]. HER2 was overexpressed in a proportion of patients with NSCLC and related to tumorigenesis of NSCLC [13]. HER2 protein overexpression is observed in $6-35 \%$ of patients with NSCLC, and HER2 gene amplification is noted in 10-20\% of such patients [13]. Subsets of patients with high HER2 immunohistochemical (IHC) expression (score of 3+) were found to have a good response to HER2-targeted antibody, trastuzumab [7, 9]. Moreover, several emerging approaches to target HER2-positive NSCLC have been established, and clinical trials are ongoing to evaluate the efficacy of new HER2-targeted therapies, such as trastuzumab emtansine and margetuximab [11].

Canine primary lung cancer (cPLC) is relatively uncommon in dogs compared to humans, with an estimated incidence of 1.5-4.2 cases per 10,000 dogs [3,4]. However, its incidence is increasingly reported because of improved diagnostic procedures, increased pet longevity, and environmental changes [17]. Surgical excision is a more likely effective therapy for dogs, in which surgical remission could be achieved, and the median survival time is 330 days in these cases but 28 days in dogs that could not be rendered free of visible disease [16]. Although systemic therapy is required for dogs with late-stage cPLC, chemotherapy has been largely unrewarding in the gross disease setting [21]. Treatment with molecular- and antigen-targeted therapies could be beneficial,

*Correspondence to: Kato, D.: feetkato@yahoo.co.jp

(Supplementary material: refer to PMC https://www.ncbi.nlm.nih.gov/pmc/journals/2350/)

O2020 The Japanese Society of Veterinary Science

This is an open-access article distributed under the terms of the Creative Commons Attribution Non-Commercial No Derivatives (by-nc-nd) License. (CC-BY-NC-ND 4.0: https://creativecommons.org/licenses/by-nc-nd/4.0/) 
but such targeted therapies have yet to be thoroughly examined in dogs with cPLC [21].

As with human cancer, HER2 overexpression has been reported in dogs with canine mammary gland carcinoma, transitional cell carcinoma, and apocrine gland anal sac adenocarcinoma [6, 18, 24], and HER2-targeted therapies, such as lapatinib and HER2targeting recombinant Listeria vaccines, have shown an anti-tumor effect on canine HER2-positive cancers [12, 18]. HER2 could be a therapeutic target and diagnostic marker for HER2-positive cPLC, but HER2 expression in cPLC is still unclear. This study aimed to evaluate HER2 mRNA and protein expression in cPLC tissues.

To evaluate mRNA expression of HER2, fresh cPLC $(n=6)$ and normal lung $(n=4)$ tissues were obtained from dogs with cPLC and healthy beagles, respectively. The cPLC tissues were obtained from dogs with cPLC at the Veterinary Medical Center of Tokyo between April 2017 and December 2018. To investigate the IHC expression of HER2, paraffin-embedded tissues of cPLC $(n=16)$ were analyzed. The tissues were surgically removed between January 2011 and December 2016. The tissues samples were diagnosed by veterinary pathologists certified by the Japanese College of Veterinary Pathologists at the Department of Veterinary Pathology at the University of Tokyo. All patients underwent clinical staging by thoracic radiography and computed tomography.

Permission for the collection and use of resected tissue for this study was obtained from the owners. Healthy dog tissue was obtained from healthy beagles euthanized for other experiments. All procedures were approved by the Animal Care and Use Committee at the University of Tokyo (approval number, P17-074).

The total RNA was extracted and reverse transcribed using a transcriptase (ReverTra Ace, Toyobo, Osaka, Japan). Real-time polymerase chain reaction (PCR) was performed using a premix reagent (THUNDERBIRD SYBR qPCR Mix, Toyobo), specific primers for HER2 (forward primer, CAGCCCTGGTCACCTACAA; reverse primer, CCACATCCGTAGACAGGTAG), and a real-time PCR system (StepOnePlus, Thermo Fisher Scientific, Waltham, MA, USA). mRNA expression was analyzed using the standard curve method, and expression value was normalized using gapdh (forward primer, TGACACCCACTCTTCCACCTTC; reverse primer, CGGTTGCTGTAGCCAAATTCA) as an internal control.

The cPLC tissues were retrospectively evaluated by IHC analysis. All samples were fixed in 10\% neutral buffered formalin, embedded in paraffin wax, and cut into $4-\mu$ m-thick serial sections. Paraffin-embedded tumor sections were dewaxed and rehydrated in xylene and graded ethanol. Then, antigen retrieval was performed using Dako Target Retrieval Solution, $\mathrm{pH} 9.0$ (Agilent Technologies, Santa Clara, CA, USA), by microwaving for $15 \mathrm{~min}$ at $750 \mathrm{~W}$. After washing with Tris-buffered saline containing $0.1 \%$ Tween 20 (TBS-t), endogenous peroxidase was blocked with $3 \%$ hydrogen peroxide in methanol for 10 min. Then, specimens were washed with TBS-t and incubated in $8 \%$ skimmed milk for $1 \mathrm{hr}$ at $20-28^{\circ} \mathrm{C}$ to reduce nonspecific binding before overnight incubation with primary antibodies, which included mouse IgG1 anti-HER2 monoclonal antibodies (clone, CB-11, Leica Biosystems, Wetzlar, Germany) diluted $1: 40$, at $4^{\circ} \mathrm{C}$ in a humidified chamber. A negative control was incubated with purified mouse IgG1, $\kappa$ isotype antibody (clone, MG1-45, BioLegend, San Diego, CA, USA), under identical conditions. After washing with TBS-t, sections were incubated with a horseradish peroxidase (HRP)-conjugated anti-mouse antibody (Envision+ System-HRP Labeled Polymer; K4001; Agilent Technologies) for 30 min at $20-28^{\circ} \mathrm{C}$.

Thereafter, the sections were washed with TBS-t, incubated with 3,3' diaminobenzidine (Dojindo Laboratories, Rockville, MD, USA) solution for 3 min, and counterstained with Mayer's hematoxylin. In the negative control, sections were subjected to the same procedures. The results were quantified based on the recent guidelines proposed by the American Society of Clinical Oncology/College of American Pathologists (ASCO/CAP) [23].

The statistical method and software used were Fisher's exact test (R Development Core Team, 2018) and the beeswarm R package (version 0.2.3, 2016). A $P$-value $<0.05$ was considered statistically significant.

mRNA expression levels of HER2 were evaluated in cPLC and normal lung tissues. Variation in the mRNA expression of HER2 in cPLC tissues was higher than that in normal tissues and high HER 2 mRNA expression was more frequently observed in cPLC tissues compared to normal lung tissues (Fig. 1). Of 6 cPLC samples, 5 expressed higher HER 2 mRNA expression than any normal samples $(P<0.05)$.

In the IHC analysis, 16 cPLC tissue samples were collected from 16 dogs ( 5 castrated male, 3 intact male, 7 spayed female, and 1 intact female dogs) of different breeds (5 Chihuahuas, 4 Miniature Dachshunds, 2 Shih Tzu, 1 Beagle, 1 English Pointer, 1 Saluki, and 1 Toy Poodle). The mean age was $12.3 \pm 1.3$ years (population standard deviation), ranging from 10.2 to 15.1 years. Three tumors were located on right cranial, 3 on the right middle, 2 on the right caudal, 1 on the left cranial, and 7 on the left caudal area (Table 1).

HER2-positive cPLC tissues demonstrated strong and broad staining of the circumferential membrane of cPLC cells and negative or weakly positive staining on peri-tumor normal cells and normal lung tissues via IHC staining (Fig. 2). We analyzed the HER2 expression score based on the ASCO/CAP guidelines (Table 2) to evaluate the staining pattern. Representative staining patterns of each score are shown in Fig. 2. HER2 expression score analysis

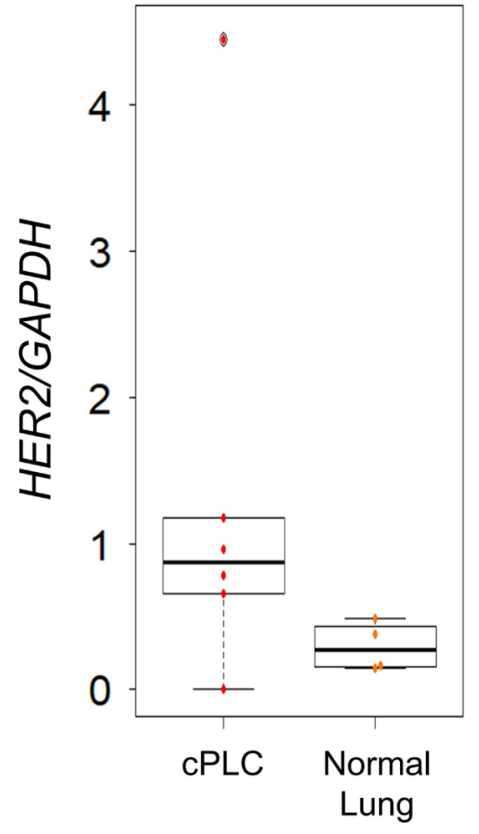

Fig. 1. Human epidermal growth factor receptor 2 (HER2) mRNA expression in canine primary lung cancer $(\mathrm{cPLC})(\mathrm{n}=6)$ and normal lung tissues $(\mathrm{n}=4)$. Of 6 cPLC samples, 5 expressed higher HER 2 mRNA than any normal samples $(P<0.05)$. 
Table 1. Characteristics of dogs and the corresponding human epidermal growth factor receptor 2 expression

\begin{tabular}{|c|c|c|c|c|c|c|c|c|c|}
\hline \multirow{2}{*}{ No. } & \multirow{2}{*}{ Breed $^{\text {a) }}$} & \multirow{2}{*}{$\begin{array}{c}\text { Age } \\
\text { (years) }\end{array}$} & \multirow{2}{*}{$\operatorname{Sex}^{b)}$} & \multirow{2}{*}{ Location } & \multicolumn{3}{|c|}{ TNM classification } & \multirow{2}{*}{ Classification } & \multirow{2}{*}{$\mathrm{IHC}^{\mathrm{c})}$ score } \\
\hline & & & & & $\mathrm{T}$ & $\mathrm{N}$ & $\mathrm{M}$ & & \\
\hline 1 & $\mathrm{CH}$ & 13.2 & $\mathrm{MC}$ & Right cranial & $\mathrm{T} 1$ & No & M0 & Adenocarcinoma & $1+$ \\
\hline 2 & $\mathrm{CH}$ & 11.5 & FS & Right middle & $\mathrm{T} 1$ & No & M0 & Adenocarcinoma & $1+$ \\
\hline 3 & $\mathrm{TP}$ & 11.3 & $\mathrm{MC}$ & Left caudal & $\mathrm{T} 1$ & N1 & M0 & Adenocarcinoma & $1+$ \\
\hline 4 & SAL & 11.8 & $\mathrm{M}$ & Left caudal & $\mathrm{T} 1$ & N1 & M0 & Adenocarcinoma & $1+$ \\
\hline 5 & SHI & 10.2 & FS & Left caudal & $\mathrm{T} 1$ & No & M0 & Adenocarcinoma & $2+$ \\
\hline 6 & $\mathrm{CH}$ & 12.3 & $\mathrm{MC}$ & Left caudal & $\mathrm{T} 1$ & No & M0 & Adenocarcinoma & $2+$ \\
\hline 7 & MLT & 13.6 & $\mathrm{MC}$ & Left caudal & $\mathrm{T} 1$ & No & M0 & Adenocarcinoma & $2+$ \\
\hline 8 & SHI & 11.8 & $\mathrm{MC}$ & Left cranial & $\mathrm{T} 1$ & No & M0 & Adenocarcinoma & $2+$ \\
\hline 9 & MD & 11.2 & FS & Right middle & $\mathrm{T} 1$ & No & M0 & Adenocarcinoma & $2+$ \\
\hline 10 & $\mathrm{CH}$ & 11.2 & M & Right cranial & $\mathrm{T} 1$ & No & M0 & Adenocarcinoma & $2+$ \\
\hline 11 & $\mathrm{CH}$ & 14.2 & $\mathrm{~F}$ & Right cranial & $\mathrm{T} 1$ & No & M0 & Adenocarcinoma & $2+$ \\
\hline 12 & MD & 15.1 & M & Right middle & $\mathrm{T} 1$ & No & M0 & Adenocarcinoma & $3+$ \\
\hline 13 & MD & 12.3 & FS & Left caudal & $\mathrm{T} 2$ & No & M1 & Adenocarcinoma & $3+$ \\
\hline 14 & BG & 13.0 & FS & Right caudal & $\mathrm{T} 1$ & No & M0 & Alveolar carcinoma & $3+$ \\
\hline 15 & $\mathrm{EP}$ & 12.8 & FS & Right caudal & $\mathrm{T} 1$ & No & M0 & Bronchial cell carcinoma & $2+$ \\
\hline 16 & MD & 12.3 & FS & Left caudal & $\mathrm{T} 1$ & No & M0 & Squamous cell carcinoma & $1+$ \\
\hline
\end{tabular}

a) CH, Chihuahua; TP, Toy Poodle; SAL, Saluki; SHI, Shih Tzu; MLT, Maltese; MD, Miniature Dachshund; BG, Beagle; EP, English Pointer. b) M, male; MC, male castrated; F, female; FS, female spayed. c) IHC, immunohistochemistry.

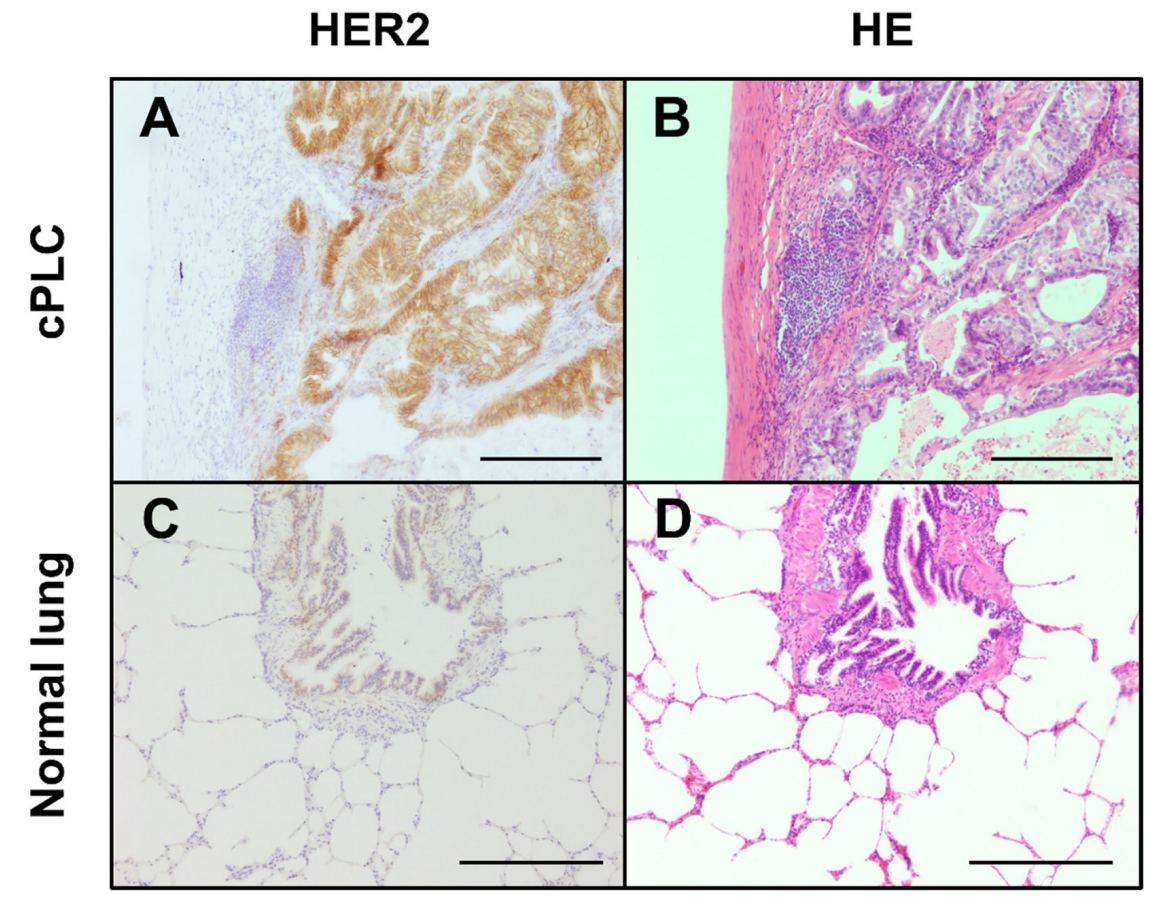

Fig. 2. Representative staining pattern of human epidermal growth factor receptor 2 (HER2) in canine primary lung cancer (cPLC) (A) and normal lung tissue (C). Circumferential membrane staining is complete and intense in cPLC. (B, D) Hematoxylin and eosin staining of cPLC and normal tissues. Scale bar, $200 \mu \mathrm{m}$.

demonstrated that 3 samples (19\%) scored 3+; 8 samples (50\%), 2+; 5 samples (31\%), 1+; and 0 sample (0\%), 0 (Table 3 and Supplementary Fig. 1). In total, $69 \%$ of cPLC tissues were HER2 positive (scored $\geq 2+$ ). There was no relationship between HER2 expression scores and clinical characteristics (Table 1).

In the current study, high HER2 mRNA expression was frequently found in cPLC tissues and circumferential membrane staining of canine HER2 in cPLC. HER2 expression was strongly detected in $69 \%$ of cPLC tissues, while HER2 was negative in normal lung tissues. Because most cases were resectable early-stage diseases and the number of patients was limited, we could not observe a correlation between HER2 expression and clinical characteristics, such as TNM classification, clinical stage, and histologic subtype. Further studies are required to investigate the association between HER2 expression and malignancies in cPLC. 
Table 2. Human epidermal growth factor receptor 2 scoring methods proposed by the American Society of Clinical Oncology/College of American Pathologists

\begin{tabular}{cl}
\hline Score & \multicolumn{1}{c}{ Description } \\
\hline $3+$ & $\begin{array}{l}\text { Circumferential membrane staining that is complete, intense, and } \\
\text { in }>10 \% \text { of tumor cells }\end{array}$ \\
\hline $2+$ & $\begin{array}{l}\text { Circumferential membrane staining that is incomplete and/or } \\
\text { weak } / \text { moderate and in }>10 \% \text { of tumor cells } \\
\text { or } \\
\text { Complete and circumferential membrane staining that is intense and } \\
\text { in }<10 \% \text { of tumor cells }\end{array}$ \\
\hline $1+$ & $\begin{array}{l}\text { Incomplete membrane staining that is faint/barely perceptible and } \\
\text { in }>10 \% \text { of tumor cells }\end{array}$ \\
& $\begin{array}{l}\text { No staining observed } \\
\text { or } \\
0\end{array}$ \\
& $\begin{array}{l}\text { Membrane staining that is incomplete and is faint } / \text { barely perceptible } \\
\text { and }<10 \% \text { of tumor cells }\end{array}$ \\
\end{tabular}

Table 3. Human epidermal growth factor receptor 2 scores in canine primary lung cancer tissue samples

\begin{tabular}{lcccc}
\hline & \multicolumn{2}{c}{ Negative } & \multicolumn{2}{c}{ Positive } \\
\hline Score & 0 & $1+$ & $2+$ & $3+$ \\
Number $(\%)$ & $0(0 \%)$ & $5(31 \%)$ & $8(50 \%)$ & $3(19 \%)$ \\
\hline
\end{tabular}

Our results demonstrated that approximately $70 \%$ of cPLC overexpressed HER 2 . Recently, Lorch et al. reported that $38 \%$ of canine pulmonary adenocarcinoma possessed somatic HER2 point mutation mainly in hotspot V659E transmembrane domain and constitutively activated HER2 downstream signaling [10]. Importantly, they demonstrated that no cases having HER2 point mutation showed overexpression of HER $2 \mathrm{mRNA}$ and protein, as similar to typical finding that HER2 amplification/overexpression and gene mutations are mutually exclusive [10]. They also showed one out of HER2 wild type four tissues overexpressed HER2 protein [10]. The discrepancy in frequency of HER2 protein overexpression between the reports and our results could be because of the difference in clones of antibody, populations and/or scoring systems. Overall, through our and Lorch et al. findings, majority of cPAC possessed HER2 abnormality including overexpression and gene mutations, which would be beneficial findings for diagnosis and development of a novel therapy.

An increasing number of HER2-targeted therapies are developed in human medicine and some drugs, such as lapatinib, afatinib, and trastuzumab, showed clinical benefit for patients with NSCLC [11]. Since cPLC share clinic pathologic features with NSCLC [10] and canine HER2 has 92\% amino acid homology with human HER2 [20], HER2-targeted therapies, which showed anti-tumor effect against NSCLC, could exhibit clinical benefit for cPLC. In fact, one of the HER2-targeted therapies, neratinib, have shown an anti-tumor effect on HER2 ${ }^{\mathrm{V} 659 \mathrm{E}} \mathrm{cPLC}$ cell line which displayed constitutive activation of HER2 downstream signaling in vitro [10]. Moreover, other types of HER2-targeted therapies, such as trastuzumab and HER2-targeting recombinant Listeria vaccines, have shown potential anti-tumor effect against cPLC cell lines and dogs with osteosarcoma [10, 12]. Because these therapies are independent on HER2 downstream signaling, they might be potential novel therapies for dogs with HER2-positive cPLC. Above all, there are several therapeutic options targeting HER2 in cPLC, and our preliminary data would lead to further preclinical and clinical evaluation of these HER2 targeted therapies in cPLC.

\section{REFERENCES}

1. Awada, G., Gombos, A., Aftimos, P. and Awada, A. 2016. Emerging drugs targeting human epidermal growth factor receptor 2 (HER2) in the treatment of breast cancer. Expert Opin. Emerg. Drugs 21: 91-101. [Medline] [CrossRef]

2. Casalini, P., Iorio, M. V., Galmozzi, E. and Ménard, S. 2004. Role of HER receptors family in development and differentiation. J. Cell. Physiol. 200: 343-350. [Medline] [CrossRef]

3. Dorn, C. R., Taylor, D. O., Frye, F. L. and Hibbard, H. H. 1968. Survey of animal neoplasms in Alameda and Contra Costa Counties, California. I. Methodology and description of cases. J. Natl. Cancer Inst. 40: 295-305. [Medline]

4. Dobson, J. M., Samuel, S., Milstein, H., Rogers, K. and Wood, J. L. N. 2002. Canine neoplasia in the UK: estimates of incidence rates from a population of insured dogs. J. Small Anim. Pract. 43: 240-246. [Medline] [CrossRef]

5. English, D. P., Roque, D. M. and Santin, A. D. 2013. HER2 expression beyond breast cancer: therapeutic implications for gynecologic malignancies. Mol. Diagn. Ther. 17: 85-99. [Medline] [CrossRef]

6. Gama, A., Alves, A. and Schmitt, F. 2008. Identification of molecular phenotypes in canine mammary carcinomas with clinical implications: 
application of the human classification. Virchows Arch. 453: 123-132. [Medline] [CrossRef]

7. Gatzemeier, U., Groth, G., Butts, C., Van Zandwijk, N., Shepherd, F., Ardizzoni, A., Barton, C., Ghahramani, P. and Hirsh, V. 2004. Randomized phase II trial of gemcitabine-cisplatin with or without trastuzumab in HER2-positive non-small-cell lung cancer. Ann. Oncol. 15: 19-27. [Medline] [CrossRef]

8. Hurvitz, S. A. and Kakkar, R. 2012. Role of lapatinib alone or in combination in the treatment of HER2-positive breast cancer. Breast Cancer (Dove Med. Press) 4: 35-51. [Medline]

9. Langer, C. J., Stephenson, P., Thor, A., Vangel, M., Johnson D. H., Eastern Cooperative Oncology Group Study 2598. 2004. Trastuzumab in the treatment of advanced non-small-cell lung cancer: is there a role? Focus on Eastern Cooperative Oncology Group study 2598. J. Clin. Oncol. 22: 1180-1187. [Medline] [CrossRef]

10. Lorch, G., Sivaprakasam, K., Zismann, V., Perdigones, N., Contente-Cuomo, T., Nazareno, A., Facista, S., Wong, S., Drenner, K., Liang, W. S., Amann, J. M., Sinicropi-Yao, S. L., Koenig, M. J., La Perle, K., Whitsett, T. G., Murtaza, M., Trent, J. M., Carbone, D. P. and Hendricks, W. P. D. 2019. Identification of recurrent activating HER2 mutations in primary canine pulmonary adenocarcinoma. Clin. Cancer Res. 25: 5866-5877. [Medline] [CrossRef]

11. Mar, N., Vredenburgh, J. J. and Wasser, J. S. 2015. Targeting HER2 in the treatment of non-small cell lung cancer. Lung Cancer 87: $220-225$. [Medline] [CrossRef]

12. Mason, N. J., Gnanandarajah, J. S., Engiles, J. B., Gray, F., Laughlin, D., Gaurnier-Hausser, A., Wallecha, A., Huebner, M. and Paterson, Y. 2016. Immunotherapy with a HER2-targeting listeria induces HER2-Specific immunity and demonstrates potential therapeutic effects in a phase I trial in canine osteosarcoma. Clin. Cancer Res. 22: 4380-4390. [Medline] [CrossRef]

13. Mazières, J., Peters, S., Lepage, B., Cortot, A. B., Barlesi, F., Beau-Faller, M., Besse, B., Blons, H., Mansuet-Lupo, A., Urban, T., Moro-Sibilot, D., Dansin, E., Chouaid, C., Wislez, M., Diebold, J., Felip, E., Rouquette, I., Milia, J. D. and Gautschi, O. 2013. Lung cancer that harbors an HER2 mutation: epidemiologic characteristics and therapeutic perspectives. J. Clin. Oncol. 31: 1997-2003. [Medline] [CrossRef]

14. Ménard, S., Fortis, S., Castiglioni, F., Agresti, R. and Balsari, A. 2001. HER2 as a prognostic factor in breast cancer. Oncology 61 Suppl 2: 67-72. [Medline] [CrossRef]

15. Molina, J. R., Yang, P., Cassivi, S. D., Schild, S. E. and Adjei, A. A. 2008. Non-small cell lung cancer: epidemiology, risk factors, treatment, and survivorship. Mayo Clin. Proc. 83: 584-594. [Medline] [CrossRef]

16. Ogilvie, G. K., Weigel, R. M., Haschek, W. M., Withrow, S. J., Richardson, R. C., Harvey, H. J., Henderson, R. A., Fowler, J. D., Norris, A. M., Tomlinson, J., et al. 1989. Prognostic factors for tumor remission and survival in dogs after surgery for primary lung tumor: 76 cases (1975-1985). J. Am. Vet. Med. Assoc. 195: 109-112. [Medline]

17. Sabattini, S., Mancini, F. R., Marconato, L., Bacci, B., Rossi, F., Vignoli, M. and Bettini, G. 2014. EGFR overexpression in canine primary lung cancer: pathogenetic implications and impact on survival. Vet. Comp. Oncol. 12: 237-248. [Medline] [CrossRef]

18. Sakai, K., Maeda, S., Saeki, K., Nakagawa, T., Murakami, M., Endo, Y., Yonezawa, T., Kadosawa, T., Mori, T., Nishimura, R. and Matsuki, N. 2018. Anti-tumour effect of lapatinib in canine transitional cell carcinoma cell lines. Vet. Comp. Oncol. 16: 642-649. [Medline] [CrossRef]

19. Shao, X., Kuai, X., Pang, Z., Zhang, L., Wu, L., Xu, L. and Zhou, C. 2018. Correlation of Gli1 and HER2 expression in gastric cancer: Identification of novel target. Sci. Rep. 8: 397. [Medline] [CrossRef]

20. Singer, J., Weichselbaumer, M., Stockner, T., Mechtcheriakova, D., Sobanov, Y., Bajna, E., Wrba, F., Horvat, R., Thalhammer, J. G., Willmann, M. and Jensen-Jarolim, E. 2012. Comparative oncology: ErbB-1 and ErbB-2 homologues in canine cancer are susceptible to cetuximab and trastuzumab targeting. Mol. Immunol. 50: 200-209. [Medline] [CrossRef]

21. Vail, D. M., Thamm, D. H. and Liptak, J. M. 2019. Withrow \& MacEwen's Small Animal Clinical Oncology, 6th ed., pp. 507-514. Elsevier, Amsterdam

22. Vogel, C. L. and Franco, S. X. 2003. Clinical experience with trastuzumab (herceptin). Breast J. 9: 452-462. [Medline] [CrossRef]

23. Wolff, A. C., Hammond, M. E. H., Hicks, D. G., Dowsett, M., McShane, L. M., Allison, K. H., Allred, D. C., Bartlett, J. M. S., Bilous, M., Fitzgibbons, P., Hanna, W., Jenkins, R. B., Mangu, P. B., Paik, S., Perez, E. A., Press, M. F., Spears, P. A., Vance, G. H., Viale, G., Hayes D. F., American Society of Clinical Oncology College of American Pathologists. 2013. Recommendations for human epidermal growth factor receptor 2 testing in breast cancer: American Society of Clinical Oncology/College of American Pathologists clinical practice guideline update. J. Clin. Oncol. 31: 3997-4013. [Medline] [CrossRef]

24. Yoshimoto, S., Kato, D., Kamoto, S., Yamamoto, K., Tsuboi, M., Shinada, M., Ikeda, N., Tanaka, Y., Yoshitake, R., Eto, S., Saeki, K., Chambers, J. K., Kinoshita, R., Uchida, K., Nishimura, R. and Nakagawa, T. 2019. Detection of human epidermal growth factor receptor 2 overexpression in canine anal sac gland carcinoma. J. Vet. Med. Sci. 81: 1034-1039. [Medline] [CrossRef] 